\title{
The Perception of an Entrepreneur's Structural, Relational and Cognitive Social Capital among Young People in Poland - an Exploratory Study
}

\section{Paweł Ziemiańskĩ}

\begin{abstract}
The goal of the current paper is to verify how an entrepreneur's structural, relational and cognitive social capital levels are perceived by young people in Poland. The research involved a group of 374 undergraduate business students from a Polish university as participants. Participants completed a survey on entrepreneurial cognitions. It was found that participants assess the level of an entrepreneur's social capital as relatively low. Due to the fact that social capital, and its different dimensions, serve different purposes in the process of venture creation, the result obtained can be considered alarming. Its practical implications are related to the necessity to review and design activities facilitating the development of an entrepreneurial culture in Poland. The value and the originality of the paper lie in the approach that allowed us to investigate which dimensions of an entrepreneur's social capital are seen as particularly weak by people for whom launching a new business is a viable option in the near future.
\end{abstract}

Keywords: social capital, entrepreneur's social capital, entrepreneurship, nascent entrepreneurs.

\section{INTRODUCTION}

The issue of social capital has increasingly attracted the attention of entrepreneurship scholars (e.g., Stam, Arzlanian \& Elfring, 2014). One of the main reasons for that interest is the fact that establishing an operating venture is difficult and the identification of factors that may increase the probability of success is of great theoretical and practical importance. People who operate in a supportive environment (e.g., an environment in which they can create

1 Paweł Ziemiański, Ph.D., Gdańsk University of Technology, Faculty of Management and Economics, Narutowicza 11/12, 80-233 Gdańsk, Poland, e-mail: pawel.ziemianski@zie.pg.edu.pl. 
and sustain a high level of social capital) are more likely to start new ventures and become nascent entrepreneurs. This pertains to both developing and developed countries (Kolvereid \& Obloj, 1994). Entrepreneurial social capital may be perceived as a factor that is related to one's ability to gather the necessary entrepreneurial resources (Lin, Li \& Chen, 2006). Since the seminal work of Putnam (1994), scholars have attempted to identify and verify different dimensions of social capital in different social contexts. One such theoretical proposition that applies strictly to the entrepreneurial context was developed by Nahapiet and Ghoshal (1998) and later used by other scholars including Liao and Welsch (2005). Authors identified three dimensions of social capital: structural, relational and cognitive social capital. The aim of the current paper is to present and discuss the results of exploratory research aimed at the identification of attitudes of Polish students towards entrepreneurial social capital. Its indicators, proposed by Liao and Welsch, were utilized in this attempt. The described goal should be regarded as important, as the difference between perceiving various elements of the environment as supportive, indifferent or even hostile to entrepreneurs, can affect the career choices of young people. Obtaining more detailed information about the perception of levels of different social capital dimensions can also indicate areas in which actions, aimed at its enhancement, should be undertaken. It may therefore be stated that the current article is of both theoretical and practical importance as, apart from advancing what we know about the perception of social capital in Poland where a unique mixture of different developmental stages of capitalism can be observed (Ziółkowski, 2012), it can allow us to develop guidelines for policy makers and educators.

\section{LITERATURE REVIEW}

The discussion regarding social capital has been largely influenced by theoretical conceptualizations proposed by Coleman (1988) and Putnam (2000). These authors perceive social capital as resources that are the result of social networks. The relationship between people can be very close (e.g., in a family) or quite loose (e.g., in a community or an entire society). The term social capital refers to a rather fuzzy concept (Liao \& Welsch, 2003). Its ambiguity is mainly related to the fact that it has been the object of investigation of scholars with the different theoretical background. For the purpose of the current paper, it is important to indicate its main characteristics that are congruent across different conceptualizations. As the main goal of this article is the investigation of students' attitudes towards entrepreneurial social capital, the description of main theoretical approaches to social capital 
will be followed by a brief introduction of its dimensions proposed by different scholars, including those who focused on entrepreneurship research.

Social capital can be perceived as an asset that is embedded in relationships. In his seminal work, Putnam (1994) compared the performance of regional governments in Italy. His main conclusion was that these different levels of performance were related to the quality and quantity of interactions and ties between members of society. In northern Italy, people tended to be more engaged and active in various associations. This tendency was in contrast with typical attitudes and actions of people living in the south of the country who demonstrated lower levels of civic engagement. Putnam perceived this difference as a major source of the higher efficiency of northern governments. He asserted that the social capital embedded in the networks of people allows individuals (as well as governments) to engage in positive collective actions aimed at improving the current state, and to trust each other in the face of dilemmas that are inherently related to collaboration with others (Bolino \& Grant, 2016).

Even though social capital is perceived by different scholars as operating on different levels (e.g., on the group level only or on the individual level as well) and may be defined in different ways (Portes, 1998), there is an agreement that it refers to trust, obligations and social norms, in particular to the norm of reciprocity that emerges between people who are related to each other (Walker, Kogut \& Shen, 1997; Nahapret, Ghosul \& 1997). Coleman (1988) made an attempt to find common ground between different approaches to social capital and asserted that social capital is "a variety of entities with two elements in common: they all consist of some aspect of social structure, and they facilitate certain actions of actors within the structure" (p. 98). An additional crucial aspect is that social capital enables one to obtain resources and achieve goals that would be impossible or much more costly to reach without it.

In general, scholars perceive social capital as a valuable asset that can be used for the benefit of individuals and entire societies (e.g., Fukuyama, 2001). Social capital has also become an important factor in theoretical approaches explaining the differences in economic development (Woolcock, 2001). According to this author, the discourse about economic development during the Cold War era was too large extent dominated by the comparison between two drastically different ways in which countries were governed and the economic consequences of these practices. The role of communities and local and national institutions was overlooked until the last decade of the previous century, when the difficulties faced by transitional economies and the growing number of poor in wealthy societies, could not be addressed without referring to social aspects. The same holds true today with recent 
shifts in global politics and unprecedented changes whose impact is impossible to predict. Under such circumstances, social capital can become even more important (Newton \& Zmerli, 2011).

It has been argued that social capital cannot be perceived as a unidimensional construct (Ziółkowski, 2012). The fact that, as any kind of capital, it can be used to serve both a positive and negative purpose, has been the starting point for distinguishing dimensions of social capital. Rules of reciprocity and trust can be used to serve the particular interests of a single social group. Such a group can take advantage of its cohesion in order to exploit common resources at the expense of others. On the other hand, social capital can be utilized for the common benefit, as established social norms and trust may become characteristics to interaction across wider networks, even an entire society (Putnam, 2000). This important distinction between two kinds of relationships with others: social ties with those who are similar to an individual and are usually members of the same close group (e.g., family members, close friends) and those who are dissimilar and do not constitute a coherent social group with an individual (e.g., colleagues and associates), was the basis for recognizing two dimensions of social capital: bonding and bridging capital (Gittell \& Vidal, 1998; Putnam, 2000).

It is important to state that even though both of these kinds of social capital should be considered an important asset, scholars indicate that bonding capital may be easier to create and is more often available, as people are almost always members of some kind of primary group (Woolcock, 1998). Bridging capital, on the other hand, is not always available to individuals as it requires establishing relationships beyond primary groups. Its lack may have detrimental effects on an individual even in the presence of bonding capital. For example, evidence from Africa indicates that poor entrepreneurs create a very limited network of ties, whereas the networks of those who are more prosperous are much wider (Barr, 1998). The name bridging capital may be perceived as a metaphor that refers to a bridge connecting various social groups comprised of people who are different from one another. Woolcock (1998) proposed adding another level of social capital. He asserted that apart from horizontal relationships that are referred to as bonding and bridging dimensions of social capital, there is also its vertical aspect. The third dimension is the linking social capital that pertains to relationships between people, groups and those in a position of authority and formal institutions. Woolcock (2001, p. 11) described its role stating that "the capacity to leverage resources, ideas, and information from formal institutions beyond the community is a key function of linking social capital." Putnam (2000) contrasted the role of bonding and bridging social capital when he asserted that the bonding capital allows an individual to "get by" whereas the second 
one allows an individual to "get ahead." Linking capital should, in turn, allow people to gain access to resources from formal institutions, for example, banks. This kind of capital also pertains to being objectively informed by the media and receiving fair treatment in courts. The level of social capital possessed by an individual stem from relationships operating in all three dimensions and is related to opportunities that are available to an individual who wants to engage in goal-driven actions, including entrepreneurial endeavors (Szreter \& Woolcock, 2004).

A different classification of dimensions of social capital was proposed by Nahapiet and Ghoshal (1998) who distinguished the structural, the relational and the cognitive dimensions of social capital. In a vein similar to the previously presented conceptualization, Nahapiet and Ghoshal (1998) also indicated that social capital should be perceived as a multi-dimensional construct and that as different facets of social capital may be useful in certain situations, the interplay between its different dimensions is crucial for understanding how it influences results obtained by individuals, groups and entire societies. They identified the structural, the relational and the cognitive dimensions of social capital. These dimensions were later adopted by other scholars for entrepreneurial research. For example, the scale developed by Liao and Welsch and used in the research described in the current article was based on this conceptualization.

The structural dimension pertains to the pattern of connections between different actors. As Nahapiet and Ghoshal (1998, p. 244) argued, this dimension describes "who you reach and how you reach them." As social ties can be used in order to obtain various resources, dense networks of connections may be used to facilitate achieving goals that would otherwise be unavailable or would be possible at a much higher cost. The relational dimension of social capital, in turn, describes personal relationships and is therefore strongly related to norms, obligations and emotions. Identity, trust, respect, obligations and expectations, as well as norms and sanctions, are all facets of this dimension. The cognitive dimension of social capital pertains to "resources providing shared representations, interpretation and meaning among parties" (Nahapiet \& Goshal, 1998, p. 244). The authors indicate that this dimension was not previously thoroughly discussed in theoretical approaches to social capital and that it includes shared language and codes, but also narratives understood by parties.

This model of social capital was adapted by Liao and Welsch (2005) who discussed how social capital might affect decision making and actions of nascent entrepreneurs. The authors concluded that structural capital increases one's ability to enterprise as it allows nascent entrepreneurs to gain access to support, information and critical resources. They also 
connect this dimension with enhanced levels of innovativeness which can be achieved when information can be obtained from others and exchanged with them. Innovativeness is in turn related to better performance in the initial stages of a venture's existence (Rosenbusch, Brinckmann \& Bausch, 2011). Ties that an entrepreneur has with others can also be used in order to enhance a venture's legitimacy that is necessary to obtain access to financing and customers. Relational capital is in turn related to trust, respect and trustfulness. In the case of a nascent entrepreneur, this kind of social capital determines the easiness with which various resources can be accessed (i.e., their availability). Liao and Welsch (2005) describe it as "a precursor" to obtaining knowledge and other resources. Therefore, this kind of social capital is related to the propensity to enterprise. The cognitive dimension of an entrepreneur's social capital might be understood in terms of knowledge, attitudes, narratives and opinions pertaining to entrepreneurship that are shared with others. Communities that respect or admire entrepreneurs (and thus share similar cognitions about them) are more likely to act in a way that supports those who start their own ventures. Items created to measure a perceived entrepreneur's social capital are presented in Table 1.

Table 1. Liao and Welsch's entrepreneur's social capital scale

\begin{tabular}{|c|c|c|}
\hline $\begin{array}{l}\text { Structural social capital } \\
\text { (SC) }\end{array}$ & $\begin{array}{l}\text { Relational social capital } \\
\text { (RC) }\end{array}$ & $\begin{array}{l}\text { Cognitive social capital } \\
\text { (CC) }\end{array}$ \\
\hline $\begin{array}{l}\text { Item } 1 \text { SC. Many friends } \\
\text { have started new firms. } \\
\text { Item 2SC. Many of my } \\
\text { family and kin have started } \\
\text { new firms. }\end{array}$ & $\begin{array}{l}\text { Item } 1 \text { RC. Young people } \\
\text { are encouraged to be } \\
\text { independent and start } \\
\text { their own businesses. } \\
\text { Item } 2 \text { RC. State and local } \\
\text { governments provide good } \\
\text { support for those starting } \\
\text { new firms. } \\
\text { Item } 3 \text { RC. Banks and other } \\
\text { investors go out their } \\
\text { way to help new firms get } \\
\text { started. } \\
\text { Item } 4 \text { RC. Other } \\
\text { community groups provide } \\
\text { good support for those } \\
\text { starting new firms. }\end{array}$ & $\begin{array}{l}\text { Item } 1 \mathrm{CC} \text {. Those with } \\
\text { a successful business get } \\
\text { a lot of attention and } \\
\text { admiration. } \\
\text { Item } 2 \mathrm{CC} \text {. There are many } \\
\text { examples of well-respected } \\
\text { people who made success } \\
\text { for themselves by starting } \\
\text { a new business. } \\
\text { Item3 CC. The local } \\
\text { media does a good job of } \\
\text { covering local business } \\
\text { news. } \\
\text { Item } 4 \text { CC. Most of the } \\
\text { leaders in this community } \\
\text { are people who own } \\
\text { businesses. }\end{array}$ \\
\hline
\end{tabular}

Source: Liao \& Welsch (2005). 


\section{RESEARCH METHODS}

The goal of the study is to verify attitudes of Polish students towards entrepreneurial social capital (in particular to identify the perceived levels of different dimensions of social capital of entrepreneurs). The scale proposed by Liao and Welsch and described above was used in this attempt. The current research should be described as exploratory, as only a group of students from a single Polish university took part in the study. Students usually do not have a lot of meaningful entrepreneurial experience and their opinions about entrepreneurship are based on less reliable sources which should also be noted. However, they can still be regarded as an important group as they will need to make a career choice in the near future and starting their own ventures is one of the viable options (either right after becoming graduates or after gaining some work experience). In efficiency driven European economies (including Poland) there is a growing proportion of young people who decide to pursue an entrepreneurial career (Kelley et al., 2015). Therefore, learning about the perception of an entrepreneur's capital among young people can be particularly important for designing actions and policies aimed at developing entrepreneurial attitudes and facilitating venture creation.

Results presented in the article were obtained in a wider survey study on entrepreneurial cognitions conducted with a group of 374 undergraduate students at a business faculty of a Polish university as study participants. Among the 374 people who participated in the study, there were 240 women (64.17\%) and 133 men. One study participant did not indicate his/her gender. Participants' average age was 21.57 with a standard deviation of 1.23.

Study participants were asked to indicate the extent to which they agree with statements included in Liao and Welsch (2005) entrepreneur's social capital scale. A Likert scale ranging from 1 ("completely disagree") to 7 ("completely agree") was used. The preparation of the scale involved its translation into Polish and a subsequent back translation. Any discrepancies between the original scale and the result of the back translation were discussed and resolved in discussion with a bilingual person. Three items (Item $1 \mathrm{RC}$, Item $1 \mathrm{CC}$ and Item $2 \mathrm{CC}$ ) were clarified and words "in my society" were added to their content. The final version of the scale before the translation and its Polish version used in the current study can be found in the appendix.

\section{ANALYSIS/STUDY/RESULTS}

In the first part of the statistical analysis, the reliability of the Polish version of the scale proposed by Liao and Welsch (2005) was verified. As social capital 
is a multidimensional construct Cronbach's alpha was calculated for each of three dimensions separately. The alphas obtained are presented in Table 2.

Table 2. Cronbach's alphas for each for three dimensions of entrepreneur's social capital

\begin{tabular}{ll}
\hline Dimension & Cronbach's Alpha \\
\hline Structural social capital (SC) & 0.70 \\
Relational social capital (RC) & 0.78 \\
Cognitive social capital (CC) & 0.71 \\
\hline
\end{tabular}

The results obtained indicate that the Polish version of the scale, designed by Liao and Welsch (2005), used in this study can be considered reliable. For each of the dimensions of social capital an acceptable reliability level was obtained: Cronbach's alpha at the level of 0.7 and above is satisfactory, in particular when scales are comprised of a small number of items (Bedyńska \& Brzezicka, 2007). Additionally, further statistical analysis of the scale revealed that none of the reliability coefficients could be improved by deleting an item or items included. It should be noted however that the reliability pertains only to the scale and not the entire conceptualization of this construct. After the positive verification of the scale's reliability, the next step of statistical analysis involved the examination of relative levels of each of the social capital dimensions.

As each of the three analyzed dimensions of social capital reached a satisfactory reliability level, a single score was calculated for each dimension separately. This single score was obtained by calculating a mean score from answers given by participants to items comprising each of the subscales. Mean scores and standard deviations obtained in the entire sample for each of the three dimensions are presented in Table 3.

Table 3. Mean scores obtained for each of the three dimensions of social capital in the sample

\begin{tabular}{lll}
\hline Dimension & Mean Score & Standard Deviation \\
\hline Structural social capital (SC) & 3.24 & 1.39 \\
Relational social capital (RC) & 3.59 & 1.09 \\
Cognitive social capital (CC) & 3.86 & 1.12 \\
\hline
\end{tabular}

There are no norms that would allow us to draw firm conclusions about the obtained levels of social capital dimensions and their interpretation needs to be done cautiously. It seems however justifiable to state that the participants seem to assess this capital as rather low. As presented in Table 4 
the level of each of the dimensions was on average assessed to be significantly lower than the midpoint of the scale used in the current study (i.e., 4).

Table 4. t-Student test values and significance levels indicating differences between mean scores obtained for each of the three dimensions of social capital and the midpoint of the scale used in the current study

\begin{tabular}{lll}
\hline Dimension & $\mathbf{t}-$ Student test value & Significance level \\
\hline Structural social capital (SC) & -10.47 & $\mathrm{p}<0.001$ \\
Relational social capital (RC) & -7.26 & $\mathrm{p}<0.001$ \\
Cognitive social capital (CC) & -2.49 & $\mathrm{p}<0.05$ \\
\hline
\end{tabular}

An entrepreneur's social capital is an important asset that can be used in the process of venture creation and the perception of study participants who indicated that its level is rather low can be regarded as alarming. As each of the dimensions of social capital is also believed to serve different purposes, it is important to verify whether the perceived levels presented in Table 3 differ significantly. A statistical analysis was conducted to serve this purpose and the t-Student test for dependent groups was used. It revealed that differences between mean levels of analyzed dimensions of perceived social capital were significant:

- The perceived level of structural social capital $(M=3.24)$ was significantly lower than the perceived level of relational social capital $(M=3.59), t(370)=-4.37, p<0.001$

- The perceived level of structural social capital $(M=3.24)$ was significantly lower than the perceived level of cognitive social capital $(M=3.86), t(370)=-8.32, p<0.001$

- The perceived level of relational social capital $(M=3.59)$ was significantly lower than the perceived level of cognitive social capital $(M=3.86), t(369)=-8.59, p<0.001$

\section{DISCUSSION}

The current study revealed that levels of entrepreneur's social capital are perceived as rather low by young people-Polish undergraduate university students. Due to the fact that young people in efficiency-driven European countries (this cluster includes Poland) are likely to consider creating their own ventures in comparison to people from other countries (Kelley et al., 2015), this group seems to be of particular importance in entrepreneurial research. Additionally, a business students' curriculum includes courses that enhance knowledge and skills related to starting and running own business. 
The fact that the level of entrepreneurs' social capital is perceived as low by this group can be considered alarming, in particular when the benefits of utilizing social capital are considered.

Liao and Welsch (2005) described different aspects of social capital as serving different purposes. Structural capital is supposed to enhance a nascent entrepreneur's ability to enterprise. It serves this purpose by allowing them to gain access to crucial information and resources. The analysis of the content of items used to measure this dimension suggests that it can also be related to specific norms and is closest to bonding capital (in the understanding of Putnam, 2000). Scale items pertain to a respondent's family and friends and their entrepreneurial experiences. It has long been argued that having family members and friends who are entrepreneurs can enhance one's propensity to start a new venture (Dunn \& Holtz-Eakin, 2000). On the one hand, they can be role models, and on the other provide insurance from business risk (Hundley, 2006). It is therefore alarming that the level of this dimension of social capital was assessed as the lowest by study participants. Relational capital of an entrepreneur is, in turn, proposed to be directly related to the ability to gain access to necessary resources. The analysis of the content of items pertaining to this dimension suggests that it can be considered as a construct closely related to linking social capital. The result obtained in the current study suggests that in Poland young people are doubtful when it comes to assessing whether institutions including banks and the government are supportive and encourage starting one's own venture. Liao and Welsh (2005) asserted that this aspect of social capital is related to the propensity to enterprise. The last - cognitive - dimension of an entrepreneur's social capital is related to what people in a community or the entire society think about entrepreneurship and entrepreneurs. The mean score obtained in the researched sample was the highest among all three dimensions. Nevertheless, it was also significantly lower than the scale's midpoint. The results obtained lead to the conclusion that policies should be implemented in order to create an entrepreneurial culture in Poland in which entrepreneurship is supported and valued.

\section{CONCLUSION}

As a final point, an attempt to interpret the reasons for relatively low levels of perceived social capital that were discovered in the current studies will be made, together with proposed directions for further research and the limitations of the current study. Growiec and Growiec (2011), who addressed the issue of low social capital levels in Eastern Europe, argued that the speed 
of social changes has not matched the speed of the economic development that has been witnessed in recent years. This may be due to these countries' cultural and historical background which is related to distrust in government (that was perceived as hostile and alien during communism) as well as other people (who were perceived as rivals for scarce resources). Even though there are multiple public and private organizations and agencies whose actions are aimed at supporting entrepreneurship in general and nascent entrepreneurs in particular, the opinions of the young people who took part in the current study seem to call for further action. It appears that the intensification of both: actions aimed at enhancing the quality and quantity of support for entrepreneurs and the dissemination of information about them is needed. It is a task in which different entities, including educators, local and national governments, and private institutions including banks and the media, have a crucial role to play.

Limitations of the current study and avenues for future research should also be described. First of all, the current study is exploratory as only one group was included - business students. Even though they are an important research group in entrepreneurial studies, they do not usually have practical entrepreneurial experience. It is important to verify how entrepreneurs who started their ventures view different dimensions of social capital. Additionally, business students should not be perceived as a representative group of young people in a particular country. Further exploration of young people's attitudes is also necessary. What is more, even though satisfactory reliability coefficients were obtained for each of the social capital dimensions, it is not known if they are the most appropriate conceptualization of social capital in the context of Polish culture. Further studies involving the model of social capital used in the current study as well as other models and attempts at verifying their reliability, validity and correlates are needed.

\section{References}

Barr, A. (1998). Enterprise performance and the functional diversity of social capital. Working Paper Series, 98-1, Institute of Economics and Statistics, University of Oxford.

Bedyńska, S., \& Brzezicka, A. (2007). Statystyczny Drogowskaz. Praktyczny Poradnik Analizy Danych. Warszawa: Academia. Wydawnictwo SWPS.

Bolino, M., \& Grant, A. (2016). The bright side of being prosocial at work, and the dark side, too: A review and agenda for research on otheroriented motives, behavior, and impact in organizations. The Academy of Management Annals, 10(1), 599-670.

Coleman, J. (1988). Social capital in the creation of human capital. American Journal of Sociology, Supplement 94, S95-S120. 
Dunn, T., \& Holtz-Eakin, D. (2000). Financial capital, human capital, and the transition to self-employment: Evidence from intergenerational links. Journal of Labor Economics, 18, 282-305.

Fukuyama, F. (2001). Social capital, civil society, and development. Third World Quarterly, 22(1), 7-20.

Gittell, R., \& Vidal, A. (1998). Community Organizing: Building Social Capital as a Development Strategy. Thousand Oaks: Sage Publications.

Growiec, K., \& Growiec, J. (2011). Trusting only whom you now, knowing only whom you trust: The joint impact of social capital and trust on individuals' economic performance and happiness in CEE countries. National Bank of Poland Working Papers, 94, 1-36.

Hundley, G. (2006). Family background and the propensity for selfemployment. Industrial Relations, 45, 377-392.

Kelley, D., Brush, C., Greene, P., Herrington, M., Ali, A., \& Kew, P. (2015) Global Entrepreneurship Monitor: Special Report. Women's Entrepreneurship 2015. Global Entrepreneurship Research Association.

Kolvereid, L., \& Obloj, K. (1994). Entrepreneurship in emerging versus mature economies: An explanatory survey. International Small Business Journal, 12(4), 14-27.

Liao, J., \& Welsch, H. (2005). Roles of social capital in venture creation: Key dimensions and research implications. Journal of Small Business Management. 43(4), 345-62.

Liao, J., \& Welsch, H. (2003). Social capital and entrepreneurial growth aspiration: A comparison of technology and non-technology-based nascent entrepreneurs. Journal of High Technology Management Research, 14, 149-170.

Lin, B.W., Li, P.C., \& Chen, J.S. (2006). Social capital, capabilities, and entrepreneurial strategies: A study of Taiwanese high-tech new ventures. Technological Forecasting and Social Change, 73(2). 168-181.

Nahapiet, J., \& Ghoshal, S. (1998). Social capital, intellectual capital and the organizational advantage. Academy of Management Review, 23(2), 242-266.

Newton, K., \& Zmerli, S. (2011). Three forms of trust and their association. European Political Science Review, 3(2),169-200.

Portes, A. (1998). Social capital: Its origins and applications in modern sociology. Annual Review of Sociology, 24, 1-24.

Putnam, R. D. (1994). Making Democracy Work: Civic Traditions in Modern Italy. Princeton: Princeton University Press.

Putnam, R. D. (2000). Bowling Alone: The Collapse and Revival of American Community. New York: Touchstone.

Rosenbusch, N., Brinckmann, J., \& Bausch, A. (2011). Is innovation always beneficial? A meta-analysis of the relationship between innovation and performance in SMEs. Journal of Business Venturing, 26, 441-457.

Stam, W., Arzlanian, S., \& Elfring, T. (2014). Social capital of entrepreneurs and small firm performance: A meta-analysis of theoretical and contextual moderators. Journal of Business Venturing, 29, 152-173. 
Szreter, S., \& Woolcock, M. (2004). Health by association? Social capital, social theory, and the political economy of public health. International Journal of Epidemiology, 33(4), 650-667.

Walker, G., Kogut, B., \& Shan, W. J. (1997). Social capital, structural holes and the formation of an industry network. Organization Science, 8(2), 109125.

Woolcock, M. (1998). Social capital and economic development: Toward a theoretical synthesis and policy framework. Theory and Society. 27(2), 151-208.

Woolcock, M. (2001). The place of social capital in understanding social and economic outcomes. ISUMA Canadian Journal of Policy Research, 2(1), 11-17.

Ziółkowski, M. (2012). Kapitały społeczny, kulturowy i materialny i ich wzajemne konwersje we współczesnym społeczeństwie polskim. Studia Edukacyjne, 22, 7-27.

\section{Appendix}

English version of the entrepreneur's social capital scale used in the current study

\begin{tabular}{|c|c|c|c|c|}
\hline \multirow[b]{2}{*}{ Many friends have started new firms } & $\begin{array}{l}\text { Completely } \\
\text { disagree }\end{array}$ & \multicolumn{3}{|c|}{$\begin{array}{l}\text { Completely } \\
\text { agree }\end{array}$} \\
\hline & 1234 & 5 & 6 & 7 \\
\hline Many of my family and kin have started new firms & 1234 & 5 & 6 & 7 \\
\hline $\begin{array}{l}\text { Young people in my society are encouraged to be } \\
\text { independent and start their own businesses }\end{array}$ & 1234 & 5 & 6 & 7 \\
\hline $\begin{array}{l}\text { State and local governments provide good support for those } \\
\text { starting new firms }\end{array}$ & 1234 & 5 & 6 & 7 \\
\hline $\begin{array}{l}\text { Banks and other investors go out their way to help new firms } \\
\text { get started }\end{array}$ & 51234 & 5 & 6 & 7 \\
\hline $\begin{array}{l}\text { Other community groups provide good support for those } \\
\text { starting new firms }\end{array}$ & 1234 & 5 & 6 & 7 \\
\hline $\begin{array}{l}\text { Those with successful businesses in my society get a lot of } \\
\text { attention and admiration }\end{array}$ & 1234 & 5 & 6 & 7 \\
\hline $\begin{array}{l}\text { There are many examples in my society of well-respected } \\
\text { people who made success for themselves by starting a new } \\
\text { business }\end{array}$ & 1234 & 5 & 6 & 7 \\
\hline The local media does a good job of covering local business & 1234 & 5 & 6 & 7 \\
\hline $\begin{array}{l}\text { news } \\
\text { Most of the leaders in this community are people who own } \\
\text { businesses }\end{array}$ & 1234 & 5 & 6 & 7 \\
\hline
\end{tabular}


Polish version of the entrepreneur's social capital scale used in the current study

\begin{tabular}{|c|c|c|c|c|c|c|c|}
\hline \multirow[b]{2}{*}{ Mam wielu znajomych, którzy założyli własne firmy } & \multicolumn{4}{|c|}{$\begin{array}{l}\text { łkowicie } \\
\text { zgadzam }\end{array}$} & \multicolumn{3}{|c|}{$\begin{array}{l}\text { Całkowicie } \\
\text { się zgadzam }\end{array}$} \\
\hline & & 2 & 32 & & 5 & 6 & 7 \\
\hline Wiele osób z mojej rodziny i krewnych rozpoczęło własną działalność & & 2 & 3 & & 5 & 6 & 7 \\
\hline $\begin{array}{l}\text { Młodzi ludzie w moim środowisku są zachęcani do tego, aby być } \\
\text { niezależnymi i zakładać własne firmy }\end{array}$ & & 2 & 3 & & 5 & 6 & 7 \\
\hline $\begin{array}{l}\text { Państwo oraz samorządy zapewniają dobre wsparcie osobom } \\
\text { rozpoczynającym własną działalność }\end{array}$ & & 2 & & & 5 & 6 & 7 \\
\hline $\begin{array}{l}\text { Banki i inwestorzy robią, co tylko możliwe, żeby pomóc wystartować } \\
\text { nowym firmom. }\end{array}$ & & & 3 & & 5 & 6 & 7 \\
\hline $\begin{array}{l}\text { Inne grupy w społeczeństwie zapewniają dobre wsparcie osobom } \\
\text { rozpoczynającym własną działalność }\end{array}$ & & & & & 5 & 6 & 7 \\
\hline $\begin{array}{l}\text { W moim środowisku osoby, które osiągają sukces w biznesie, zyskują } \\
\text { wiele uwagi i są podziwiane }\end{array}$ & & & 3 & & 5 & 6 & 7 \\
\hline $\begin{array}{l}\text { W mojej społeczności jest wiele przykładów szanowanych osób, } \\
\text { które osiągnęły sukces zakładając nową firmę }\end{array}$ & & & 3 & & 5 & 6 & 7 \\
\hline Lokalne media rzetelnie prezentują lokalne informacje biznesowe & & & 3 & & 5 & 6 & 7 \\
\hline $\begin{array}{l}\text { Większość wpływowych ludzi w moim środowisku to osoby } \\
\text { posiadające własne firmy }\end{array}$ & & & 3 & & 5 & 6 & 7 \\
\hline
\end{tabular}

\begin{abstract}
Abstrakt
Celem opisanego $w$ artykule badania była weryfikacja postrzeganego przez studentów poziomu strukturalnego, relacyjnego i poznawczego kapitału społecznego przedsiębiorcy. W badaniu wzięło udział 374 studentów kierunku zwiqzanego z biznesem studiujqcych na polskiej uczelni. Osiqgnięty wynik wskazuje na to, że uczestnicy badania oceniaja poziom kapitału społecznego przedsiębiorcy jako relatywnie niski. W zwiqzku z tym, że poszczególne składowe kapitału społecznego pełniq różne funkcje $w$ procesie tworzenia przedsięwzięcia biznesowego uzyskany rezultat powinien zostać uznany za alarmujqcy. Wskazuje on na to, że niezbędne może być zintensyfikowanie działań niezbędnych do rozwoju kultury przedsiębiorczej w Polsce. W artykule omówione praktyczne wnioski wypływajqce z uzyskanych rezultatów oraz wskazano kierunki dalszych możliwych badań.

Słowa kluczowe: kapitałspołeczny, kapitałspołeczny przedsiębiorcy, przedsiębiorczość, przedsiębiorcy.
\end{abstract}

\title{
Biographical note
}

Paweł Ziemiański is an assistant professor at the Faculty of Management and Economics, Gdańsk University of Technology, Poland. His research interests are focused on nascent entrepreneurship, psychological and cultural aspects of entrepreneurship, and on power and hierarchies in organizations. 